\title{
Highlights of the 1960 Convention
}

\section{Lawrence A. Conrey}

Vice-President, C.A.S.M.T., University of Michigan, Ann Arbor, Michigan

The 60th Convention of the Central Association of Science and Mathematics Teachers will be held at the Statler Hilton Hotel in Detroit, Michigan on November 24-26, 1960. The theme of the meeting is, "Challenging Science and Mathematics Students Toward the Horizons of Knowledge."

In keeping with this theme, the opening session on Thursday evening, November 24, considers, "The Challenge of Challenging Students." Initial discussion by a panel will be extended to include those in attendence.

This initial challenge will be extended, in the subsequent two days, to many other challenges and horizons of knowledge.

\section{HORIZONS OF KNOWLEDGE:}

Our understanding of how we learn to interpret abstractions, the discovery of organized systems in the tiniest of particles, and pushing our explorations ever outward into the vast systems of outer space are stimulating examples of the ever expanding frontiers of knowledge. These "horizons" will be explored, in our general sessions with the following outstanding speakers:

"Horizons of Knowledge of the Atom"-Friday morning, November 25 .

Dr. Leonard Roellig, Department of Physics, Wayne State University, Detroit, Michigan.

"Horizons of Knowledge of the Psychology of MathematicsElementary and Secondary"-Friday morning, November 25.

Dr. Henry Van Engen, Department of Mathematics, University of Wisconsin, Madison, Wisconsin.

"Horizons of Knowledge of Space"-Friday evening, November 25

Dr. F. D. Drake, National Radio Astronomy Observatory,

Green Bank, West Virginia. Director, Project "Ozma."

"Horizons of Knowledge of the Cell"--Saturday morning, November 26.

Dr. Wayne E. Magee, Research Division, The Upjohn Company, Kalamazoo, Michigan.

In addition, a "horizon" of a different nature will be explained at the annual luncheon on Saturday, November 26. This is the horizon of a device - the teaching machine. Since these devices have received considerable mention in the public press and professional journals, we feel fortunate to have a national authority to explain them: 
"Teaching Machines on the Horizon? What Are the Implications for Science and Mathematics Teaching?"

Dr. James Holland, Psychological Laboratory, Harvard University, Cambridge, Massachusetts.

\section{Challenges}

All of Friday afternoon and the Section Meetings on Saturday morning will be devoted to various forms of challenge and at various levels. To identify those portions of the program of particular interest to you examine the following categories:

\section{Of particular interest to the elementary-school teacher:}

We are happy to announce that we have an expanded program for elementary teachers this year. The opportunities are:

In elementary mathematics:

"Implications of Modern Teaching Trends in Junior-High and High-School Mathematics for the Teaching of Arithmetic in Elementary Grades."

Dr. Bernard Gundlach, Department of Mathematics, Bowling Green State University, Bowling Green, Ohio. Director, Greater Clevcland Mathematics Project.

"Geometry in the Elementary School-A Portion of the School Mathematics Study Group Project."

Lenore John, University of Chicago Laboratory School, Chicago, Illinois-Member, 1960 Summer Writing Project-S.M.S.G.

"Important Concepts in Elementary Mathematics."

Dr. Charlotte Junge, Wayne State University, Detroit, Michigan

In elementary science:

Eight different science content sessions will be provided. In each, the resource person will identify concepts and use simple materials to illustrate these concepts. The resource people have had experience assisting many groups of elementary teachers. The content areas involved are; Air and Air Pressure, Astronomy and Space Travel, Geology, Plants, Animals, Magnetism and Electricity, Light, and Weather. Since there will be two groups of four simultaneous sessions each, each elementary teacher will have the opportunity to attend two sessions, selected at the time of registration.

Also, on Saturday morning:

"Sensible Curriculum Approaches to Elementary Science."

Jacqueline Mallinson, Assistant Editor, School Scrence AND Mathematics and Elementary Science Consultant. 
2. Of particular interest to secondary-school mathematics teachers:

a. "The Changing Mathematics Curriculum as a Vchicle for Challenge."

Dr. Phillip S. Jones, Department of Mathematics, The University of Michigan-President, National Council of Teachers of Mathematics.

b. "Challenges and Guides to the Individual Teacher Raised by the Various Study Group Projects."

Dr. Cecil B. Read, Mathematics Department, University of Wichita, Wichita, Kansas.

c. Discussion by a panel and the group in attendance of the topic: "What are some sensible content changes in high-school mathematics we should make now?"

3. Of particular interest to secondary-school teachers of science:

a. "The Changing Science Curriculum as a Vehicle for Challenge."

Dr. Vaden Miles, Department of Physics, Wayne State University, Detroit, Michigan-Past-President, National Association for Research in Science Teaching.

b. On Friday afternoon, in separate sections, consideration will be given to the writing projects in biology, chemistry and physics: "PSSC or not, what are some content adjustments on the horizon?"

Panel of teachers.

"The Chemical Bond Approach to Introductory Chemistry."

Dr. Laurence E. Strong, Department of Chemistry, Earlham College, Richmond, Indiana. Director, Chemical Bond Approach Project.

"The Chemical Education Materials Committee Approach to Introductory Chemistry."

Mr. Robert Silber, Education Secretary, American Chemical Society, Washington, D. C.--Member, Writing Committee, CEMC Project.

"The Work of the Biological Science Curriculum Study Which May Lead to Content Adjustment on the Horizon."

Phillip Fordyce, biology teacher, Oak Park-River Forest High School, Oak Park, Illinois-Member, Writing Committee, BSCS Project.

c. On Friday afternoon, general science teachers will have an opportunity to consider the impact of change in the high-school courses on the content of general science:

"A New Prestige and Importance for General Science."

David Schulert, Director of Science, Lansing Public Schools, Lansing, Michigan. 
d. On Saturday morning, in some section meetings, a series of panels concerned with the role of the individual teacher in revising the content of science courses will open the discussion for the entire group. Separate panels will be provided in general science, biology, and chemistry under the title, "What are some sensible content changes we should make now?"

Make plans now to attend the Detroit Convention. We sincerely believe that the experience will broaden your "horizons."

\section{PROPOSED CHANGES IN CASMT BY-LAWS}

The following changes in the By-Laws were proposed by the Board of Directors at the Spring Board Meeting in May. Action will be taken on these at the annual mecting in November.

ARTICLE III. OFFICERS

SECTION IV. POWER AND DUTIES OF OFFICERS:

(b) VICE-PRESIDENT:

\section{Present}

He shall act for the President in the latter's absence. He shall also serve as a member of the Executive Committee.

ARTICLE IV. BOARD OF DIRECTORS

SECTION IV. ELEC'TION, TENURE OF OFFICE, AND COMPENSATION:

\section{Present}

... Those candidates declared elected to membership of the Board of Directors shall be the required number of nominees receiving the largest number of votes cast in the annual election as described in Section III (b) of Article III. . . .

... Vacancies in the Board of Directors or list of officers shall be filled by the Board of Directors at any meeting thereof. A director so chosen shall serve until the next annual business meeting when a successor shall be elected to fill the unexpired term.

Whenever directors are elected, whether at the expiration of a term or to fill vacancies, a certificate under the seal of the Association giving the names of those elected and the term of their office shall be recorded by the Treasurer and Business Manager in the office of the recorder of deeds where the certificate of organization is recorded.

\section{Proposed}

He shall act for the President in the latter's absence. He shall serve as a member of the Executive Committee and shall act as Chairman of the Program Committee. 